\title{
SOME FRESH WATER RED AND YELLOW-GREEN ALGAE FROM NORTH-EASTERN UTTAR PRADESH, INDIA
}

\author{
Anand Kumar Srivastava and P.K. Misra* \\ P.G. Department of Botany \\ T.H.S. Kisan P.G. College, Bahraich - 271801 (U.P.) \\ E-mail: anandalgae@yahoo.com \\ *Department of Botany \\ University of Lucknow, Lucknow - 226007 \\ E-mail: misrapkm@yahoo.com
}

\begin{abstract}
The present paper deals with morpho-taxonomic descriptions of three fresh water algae belonging to classes Rhodophyceae and Xanthophyceae. These are Compsopogon Montagn, Batrachospermum Roth and Vaucheria De Candolle. They are rare in occurrence and are represented by one taxon each. All these forms have been recorded from Gonda and bahraich districts of North-Eastern Uttar Pradesh.
\end{abstract}

Key words: Algae, Rhodophyceae, Xanthophyceae, N.E. U.P.

\section{INTRODUCTION}

In the class Rhodophyceae only few genera like Porphyridium Naeg., Compsopogon Montagn, Thorea Bory, Batrachospermum Roth are known from fresh water habitats. According to Sheath and Hambrook (1988) majority of fresh water Rhodophyceae algae are found in running waters of small to mid size stream and rivers with a minimum current requirement of approximately 30 $\mathrm{cm} / \mathrm{sec}$ (Compsopogon Montagn occurs at a flow rate of $24-36 \mathrm{~cm} / \mathrm{sec}$ and Batrachospermum Roth at $44-58 \mathrm{~cm} / \mathrm{sec}$ ). The notable contribution on the genus Compsopogon Montagn and Batrachospermum Roth of India are by Bruehl and Biswas (1927), Krishnamurthy (1953, 1958), Patel and Francis (1968), Panday et al. (1973, 1976), Panday (1978), Chaugle (1980), Balakrishnan and Chaugle (1980), Sankaran (1984), Desikachary et al. (1990), Tewari and Chauhan (2000). Rintoul et al. (1999) have worked on the systamatics and biogeography of class Rhodophyceae in North
America. Ahamad and Rawheya (1999) have discovered a new species $C$. helwaii from Egypt.

The Xanthophyceae are a scarce group in India and so far only seven genera including Vaucheria De Candolle are known to occur in this country (Prasad and Mehrotra 1970). The Xanthophyceae algae from India have been reported by Venkatraman (1961), Prasad and Srivastava (1963, 1964), Srinivasan (1965), Prasad and Misra (1979), Shah et al. (1992) and Suseela and Dwivedi (2001).

In present paper 3 taxa have been described of which 2 taxa belong to the class Rhodophyceae and 1 taxon belong to class Xanthophyceae. These algae have been collected from the districts Bahraich and Gonda of North-Eastern U.P., earlier Misra et al. (2002), Misra and Srivastava (2003 a, b, 2004, 2005) have reported the member of Chlorophycean algae belonging to order Oedogoniales, Chaetophorales, Zygnematales and some Cyanophycean algae from this area. 


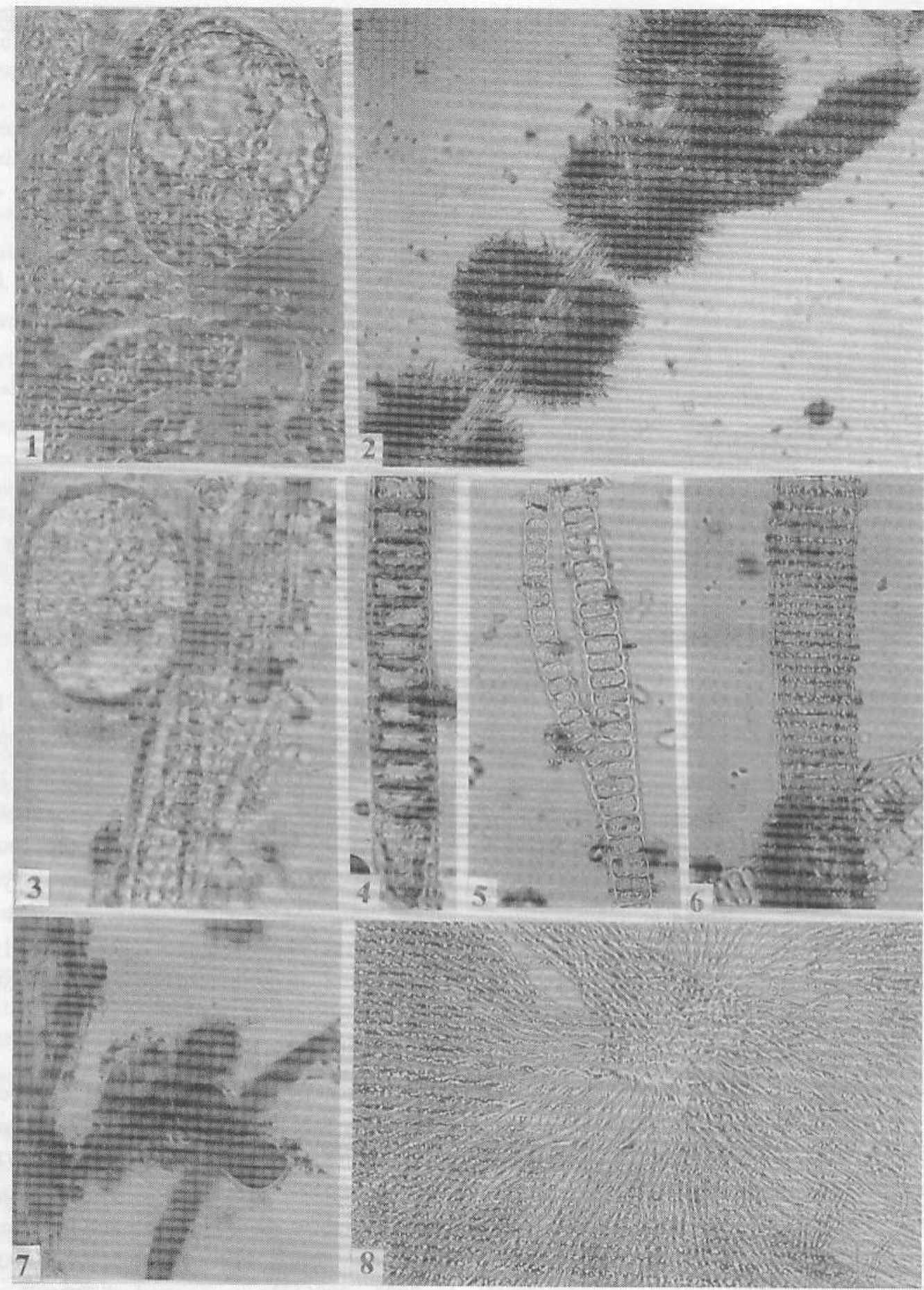

Plate 1. (Fig. 1. Vaucheria geminata De Candolle $\mathrm{x} 600$, Fig. 2. Batrachospermum moniliforme Roth $\mathrm{x}$ 100, Fig. 3. V. geminata De Candolle $\mathrm{x} 500$, Fig. 4. Compsopogon iyengarii Krishnamurthy x 400, Figs. 5, 6. C. iyengarii Krishnamurthy $\mathrm{x} 500$, Fig. 7. V. geminata De Candolle $\mathrm{x}$ 100, Fig. 8. B. moniliforme Roth $\times 200$ ). 


\section{MATERIAL AND METHODS}

Algal collections were made with the help of net fitted on extension rods. Collected materials were preserved in $4 \%$ formalin. Algae were stained with iodine and mounted in glycerine, detailed study was made under Nikon labophot II microscope.

\section{MORPHO-TAXONOMIC DESCRIPTION}

Class: Rhodophyceae

Order: Erithropeltidiales

Family: Compsopogonaceae

Genus: Compsopogon Montagn

\section{Compsopogon iyengarii Krishnamurthy}

(PI. 1, figs. 4, 5, 6)

Younger uniserrate portion $28-30 \mu \mathrm{m}$ broad, cells 10-12 $\mu \mathrm{m}$ long and discoid. Cortical cells of older filaments $12-13 \mu \mathrm{m}$ in diameter.

Localities: Golua ghat, Barua ghat, Belser road pond

Collection no. and date: $\mathrm{BAH}-25,99$ (12.01.99), GON - 202 (05.05.2002).

\section{Order: Batrachospermale}

Family: Batrachospermaceae

\section{Genus: Batrachospermum Roth}

\section{Batrachospermum moniliforme Roth}

(Pl. 1, Figs. 2, 8)

Node $60-110 \mu \mathrm{m}$ broad, inter nodal region 450 $495 \mu \mathrm{m}$ long, branch let cells 9-11 $\mu \mathrm{m}$ long, 6-7 $\mu \mathrm{m}$ broad.

Locality: Shiv temple - Radha kund

Collection no. and date: $\mathrm{BAH}-46$ (25.01.99)

Remark: According to Desikachary et al. (1990) this species has rare tendency to develop unilateral branching but present taxon frequently show unilateral branching on either side of the main axis.

\section{Class: Xanthophyceae}

Order: Hetrosiphonales
Family: Vaucheriaceae

Genus: Vaucheria De Candolle

\section{Vaucheria geminata De Candolle}

(Pl. 1, figs. 1, 3, 7)

Filaments $38-42 \mu \mathrm{m}$ in diameter, Oogonia $1-3,60$ $71 \mu \mathrm{m}$ in diameter, Oospore $48 \mu \mathrm{m}$ in diameter.

Localities: Mirzapurpond

Collection no. and date: $\mathrm{BAH}-44$ (24.01.99)

\section{RESULTS AND DISCUSSION}

Ecologically district Bahraich has a characteristic transition zone of Tarai and NorthEastern plain type of Agro-Ecological Situation (AES). Thus all the three species (two Rhodophycean and one Xanthophycean) were present in Bahraich as transition zone favoured the diversity of life, while district Gonda has a distinct North-Eastern plain zone, only one species viz. Compsopogon iyengarii Krishnamurthy was present in this district. Rich collection of Batrachospermum Roth was made from Radhakund whereas Vaucheria De Candolle was luxuriantly growing at the bank of Mirzapur pond. Genus compsopogon Montgn was rare in collection from both the districts.

\section{REFERENCES}

Ahamad, D. El. and A.El. Rawheya. 1999. New species of the genus Compsopogon Montagn viz. C. helwaii from Egypt. Phykos. 38(1\&2):37-42.

Balakrishnan, M.S. and B.B. Chaugle. 1980 . Indian Batrachospermaceae. In: Taxonomy of Algae. (eds.) Desikachary, T.V. and V.N. Raja Rao. 232 pp.

Bruehl, P. and K. Biswas. 1927. Commentationes algologicae. IV Compsopogon lividus (Hook) De Toni. J. Dept. Sci. Calcutta University. 8:1.

Chaugule, V. 1980. The morphology and taxonomy of the genus Compsopogon Montagn. J. Linn. Bot. 58:216. 
Das, C.R. 1963. The Compsopogonales of India. Proc. Nat. Sci. 29(B):242.

Desikachary, T.V., V. Krishnamurthy and M.S. Balakrishnan. 1990. Rhodophyta Monograph on Red Algae. Pub. by T.T. Maps Pub. Ltd. $279 \mathrm{pp}$.

Krishnamurthy, V. 1953. On the structure and reproduction of Compsopogon from Madras. Phytomorphology. 3:369-370.

Krishnamurthy, V. 1958. The morphology and taxonomy of the genus Compsopogon Montagn. J. Linn. Bot. 58:216.

Misra P.K. and A.K. Srivastava. 2003b. Some Desmids (Chlorophyceae) from North-eastern U.P. J. Ind. Bot. Soc. 82:85-92.

Misra, J.N. and A.K. Day. 1959. Studies on fresh water Rhodophyceae of Uttar Pradesh. Vijan Parishad Anusandhan Patrika. 2:123.

Misra, P.K. and A.K. Srivastava. 2003a. Some Chaetophoralean algae from North-eastern U.P. Vegetos. 16:65-71.

Misra, P.K. and A.K. Srivastava. 2004. Some Zygnematalean algae from North-eastern U.P. Ecoprint. 11(1):19-25.

Misra, P.K. and A.K. Srivastava. 2005. Fresh water Cyanophycean algae from North-eastern U.P. J. Ind. Bot. Soc. 84:67-75.

Misra, P.K., A.K. Srivastava and J. Prakash. 2002. Morpho-taxonomic survey on Ulotrichales and Cladophorales of North-eastern U.P. J. Ind. Bot. Soc. 80:345-350.

Panday, R.S., G.L. Tewari and D.C. Panday. 1973. A note on two form of Compsopogon from river Yamuna at Allahabad. Curr. Sci. 43(27):222.

Panday, R.S., G.L. Tewari and D.C. Panday. 1976. Observation on Compsopogon iyengarii Krishnamurthy (Rhodophyceae). Hydrobiol. 49(3):239-244.

Panday, U.C. 1978. A note on the record of Compsopogon coeruleus in Rohillkhand division. Proc. Ind. Sci. Cong. 65(111):6.
Patel, R.J. and M.A. Francis. 1968. On Batrachospermum from Gujrat. Proc. Ind. Sci. Cong. 67:230-232.

Prasad, B.N. and P.K. Misra. 1979. On a Xanthophycean Alga new to India. Curr. Sci. 48(12):544-545.

Prasad, B.N. and P.N. Srivastava. 1963. Heterothrix ulotrichoides Pascher in India. Curr. Sci. 32(6):272.

Prasad, B.N. and P.N. Srivastava. 1964. Botrydiopsis arrhiza Borzi in India. Curr. Sci. 33(19):596.

Prasad, B.N. and R.K. Mehrotra. 1970. Genus Tribonema in India. Curr. Sci. 39(22):522.

Rintoul, T.L., G.S. Robort and L.V. Morgon. 1999. Systematics and biogeography of the Compsopogonales (Rhodophyta) with emphasis on fresh water family in North America. Phycologia. 38(6):517-527.

Sankaran, V. 1984. Batrachospermum desikacharii sp nov. from Valpari Anamalis Tamilnadu. Phykos. 23 (Prof. Desikachary comm. vol.):163-170.

Shah, B.R., S.C. Gajaria and R.J. Patel. 1992. A study of Xanthophyceae from Rajasthan. Phykos. 31(1\&2):163-167.

Sheath, G. and Hambrook. 1988. Machanical adoptation of flow in fresh water red algae. $J$. Phycol. 24(1):107-111.

Srinivasan, K. 1965. Algarum species ex India Oriundae. Bull. Bot. Surv. 7:188.

Suseela, M.R. and S. Dwivedi. 2001. A contribution to fresh water algal flora of Bundalkhand region of U.P. (Chlorophyceae and Xanthophyceae). Phytotaxonomy, 1:76-81.

Tewari, A. and S.V.S. Chauhan. 2000. Three new algal forms from Agra, U.P. J. Ind. Bot. Soc. 79:79-81.

Venkatraman, G.S. 1961. Vaucheriaceae. I.C.A.R. monograph on algae. New Delhi. 112 pp. 